\title{
Multiple metastatic basal cell carcinoma with concurrent metastatic pleomorphic sarcoma in chronic lymphedema area - Case report
}

\author{
Carcinoma basocelular múltiplo e metastático concomitante a sarcoma \\ pleomórfico e metástatico em área de linfedema crônico - Relato de caso
}

\author{
Giuliano da Paz Oliveira ${ }^{1}$ \\ Cléverson Teixeira Soares ${ }^{3}$
}

\author{
Régio José Santiago Girão ${ }^{2}$ \\ Edgard Jose Franco Mello Junior ${ }^{4}$
}

\begin{abstract}
Chronic lymphedema presents as interstitial fluid retention due to a failure in the lymphatic system drainage. The affected region becomes more vulnerable immunologically and predisposed to the onset of neoplasms. Basal Cell Carcinoma is the most common sort of neoplasm, nevertheless it rarely metastisizes. Sarcomas are malignant mesenchymal neoplasms, locally aggressive, which can spread. Here is reported an infrequent case of multiple basal cell carcinoma, synchronous to a poorly differentiated pleomorphic sarcoma, both spreading to lymph nodes and arising from tissue compromised by chronic lymphedema.

Keywords: Carcinoma, basal cell; Lymphedema; Sarcoma

Resumo: Linfedema crônico se manifesta pelo acúmulo de líquido intersticial por falha da drenagem linfática. A região afetada torna-se imunologicamente vulnerável e predisposta ao desenvolvimento de neoplasias. Carcinoma basocelular é a neoplasia maligna mais comum, entretanto raramente metastatiza. Sarcomas são neoplasias mesenquimais malignas, localmente agressivas e capazes de metastatizar. Apresentamos um caso raro de múltiplos carcinomas basocelulares concomitantes a sarcoma pleomórfico pouco diferenciado, metastáticos para linfonodos, originando-se em área de linfedema crônico. Palavras-chave: Carcinoma basocelular; Linfedema; Sarcoma
\end{abstract}

\section{INTRODUCTION}

Lymphedema is a chronic disease that is manifested by the accumulation of protein-rich interstitial fluid caused by failure of lymphatic system drainage. ${ }^{1}$ Areas with chronic lymphedema are places at risk for the appearance of skin cancers such as angiosarcoma, Kaposi's sarcoma, lymphomas, melanoma, as well as basal and squamous cell carcinomas. ${ }^{1,2}$ Basal cell carcinoma (BCC) is the most common malignant neoplasm and affects more frequently men after the fourth decade of life. ${ }^{3,4}$ Metastatic basal cell carcinoma is rare and its incidence varies between $0.0028 \%$ and $0.5 \%$. ${ }^{5}$ Soft tissues sarcomas are locally aggressive neoplasms, capable of invasive and destructive growth, local recurrence and metastases. ${ }^{2,6}$ We present a rare case of a patient who developed multiple ulcerated BCC, with metastases to axillary lymph nodes, concurrently with a poorly differentiated pleomorphic sarcoma with metastases to cervical lymph nodes, in the upper limb affected by chronic lymphedema.

Received on 07.09.2011

Approved by the Advisory Board and accepted for publication on 29.12.2011.

* Study carried out at the Lauro de Souza Lima Institute (Instituto Lauro de Souza Lima - ILSL) - Bauru (SP), Brazil.

Conflict of interest: None

Financial funding: None

Undergraduate medical student, Federal University of Piauí (Universidade Federal do Piauí - UFPI) - Teresina (PI), Brazil.

MD, Dermatologist, College Professor (Faculdade Integral Diferencial - Facid) - Teresina (PI), Brazil.

MD, PhD, São Paulo State University "Júlio de Mesquita Filho" (Universidade Estadual Paulista "Júlio de Mesquita Filho" - UNESP). Pathologist, Pathological Anatomy Laboratory, at the Lauro de Souza Lima Institute (Instituto Lauro de Souza Lima - ILSL) - Bauru (SP), Brazil.

Master degree in Surgery, São Paulo State University "Júlio de Mesquita Filho" (Universidade Estadual Paulista "Júlio de Mesquita Filho" - UNESP). Surgeon of the Oncologic Surgery sector, preceptor of residency in Oncologic Surgery in Dermatology at the Lauro de Souza Lima Institute (Instituto Lauro de Souza Lima - ILSL) Bauru (SP), Brazil. 


\section{CASE REPORT}

A 75-year-old Caucasian man presented with lymphedema in the right upper limb, a sequel of surgical treatment for axillary hidradenitis suppurativa. One year after surgery, an ulcerated lesion appeared in the right axillary region followed by other similar lesions distributed throughout the upper limb (Figure 1). Three months later, he presented with a vegetating, ulcerated and bleeding lesion in his right arm, with rapid and progressive growth and approximately $6 \mathrm{~cm}$ in diameter (Figure 2). The patient denied any diseases prior to surgery or exposure to radiotherapy, arsenic or immunosuppressives. HIV and hepatitis B and $C$ serological assays were non-reactive. There was no change in face, arm, jaw or chest radiographs. Biopsies of the ulcerated lesions and vegetating lesion revealed multiple exophytic BCCs and poorly differentiated pleomorphic sarcoma, respectively. He evolved with severe anemia due to intense bleeding injuries and amputation of the affected limb was indicated.

Anatomopathological examination of the lesions of the amputated arm showed multiple BCCs with varying patterns. The largest lesion was in the axillary region, measuring $4 \mathrm{~cm}$ in the greatest diameter, predominantly with a morphea-like sclerotic pattern, infiltrating nerve bundles and blood vessel walls (Figure 3). Two of the five dissected axillary lymph nodes were affected by metastatic BCC (Figure 4). In turn, the vegetative lesion revealed an ulcerated pleomorphic dermal neoplasm, of exophytic growth, with focal areas of necrosis and infiltration of adipose tissue (Figure 5).

Immunohistochemistry of axillary BCC and lymph node metastases showed expression of cytokeratin and was negative for vimentin, muscle differentiation markers ( $\alpha$-actin smooth muscle, 1A4, musclespecific actin, HHF-35 and Desmin) (Figure 4). The pleomorphic sarcoma showed intense expression for vimentin and CD68 and focal positivity for HHF-35 and 1A4 (Figure 5). Six months after upper limb amputation, the patient had cervical lymph node metastasis with histological and immunohistochemical pattern of poorly differentiated pleomorphic sarcoma (Figure 6).
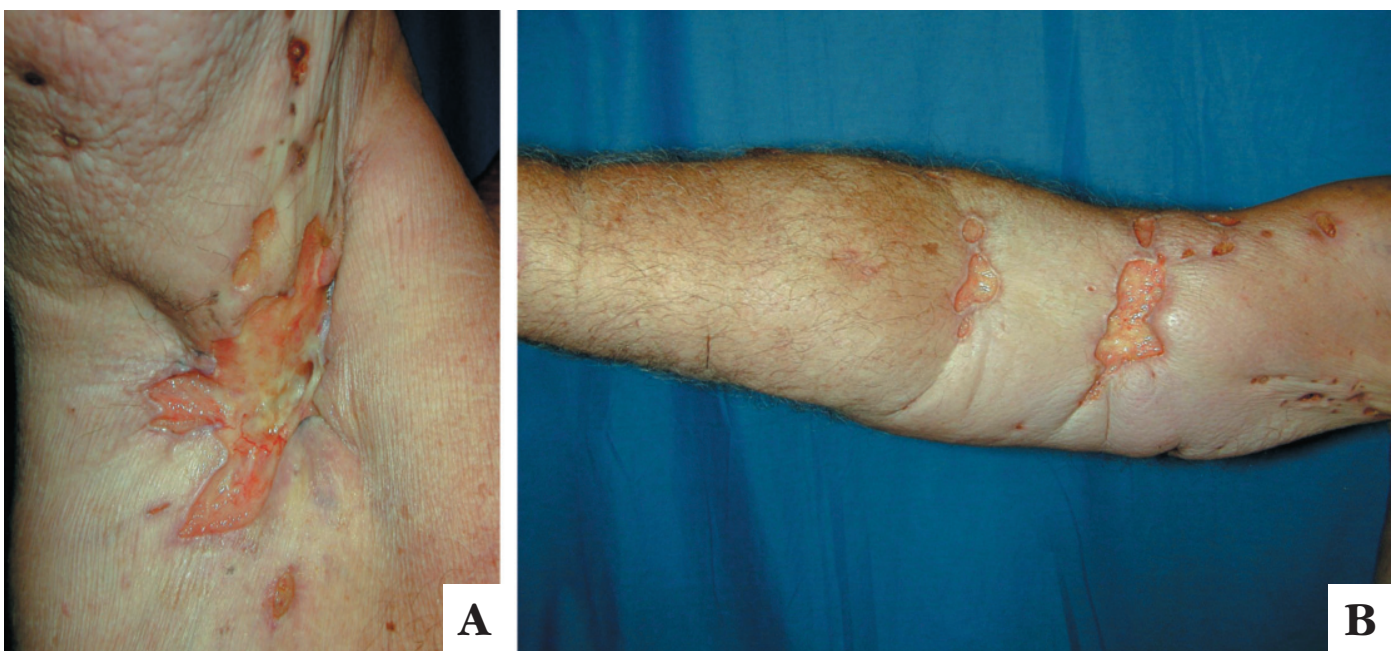

Figure 1: Basal cell carcinoma in the axilla: ulcer of $4 \mathrm{~cm}$ in diameter with pearly border and satellite lesions (A). Area of lymphedema with many ulcers: multiple basal cell carcinomas (B)
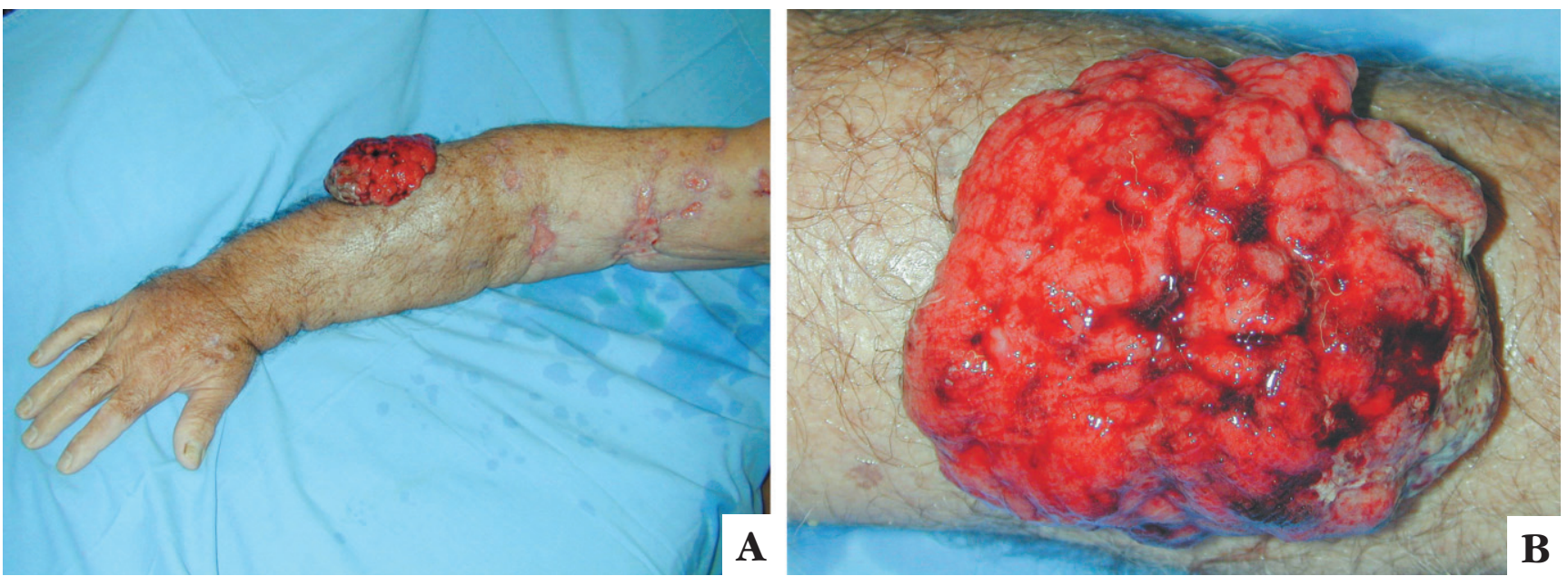

FiguRE 2: Vegetative lesion on right forearm: dermal pleomorphic sarcoma (A). Detail of previous image (B) 

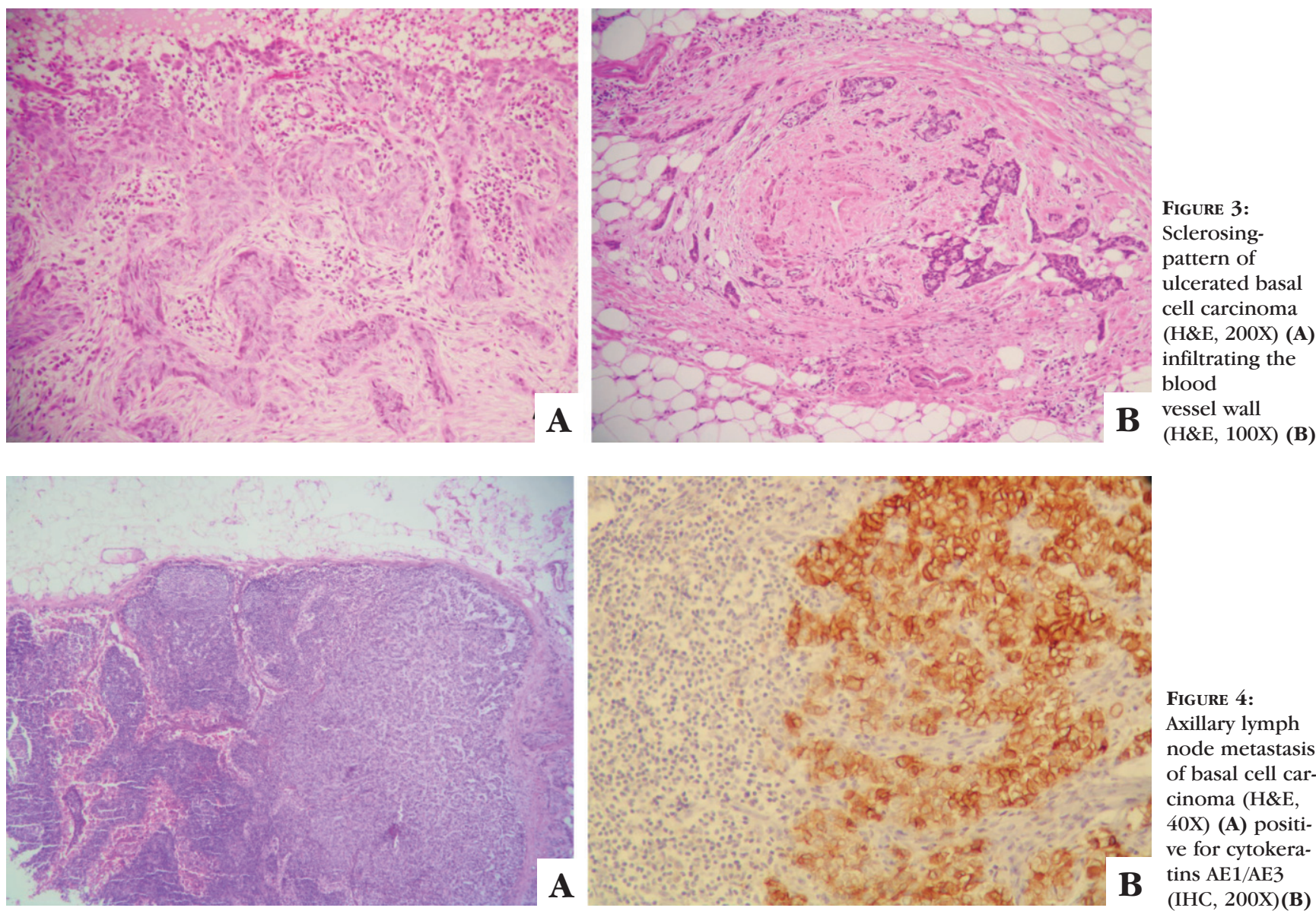

Figure 4:

Axillary lymph

node metastasis of basal cell carcinoma $(\mathrm{H} \& \mathrm{E}$, 40X) (A) positive for cytokeratins AE1/AE3 (IHC, 200X)(B)
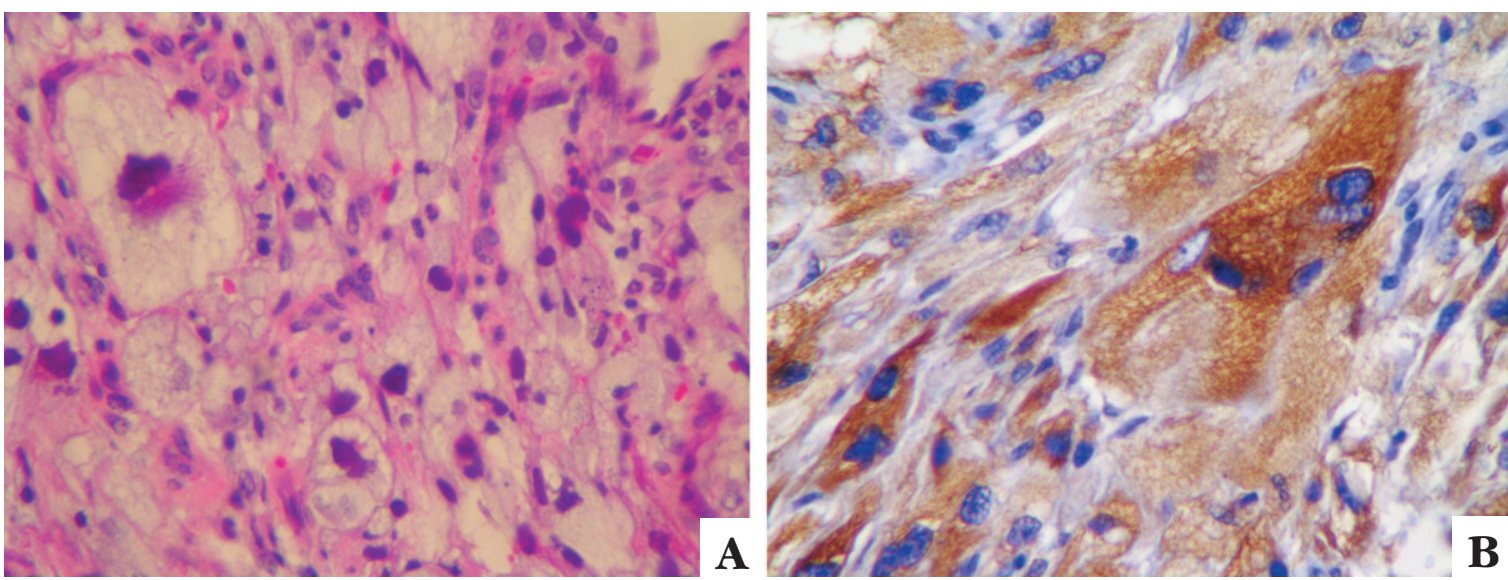

Figure 5:

Pleomorphic sarcoma: area with multivacuolated and bizarre cells $(\mathrm{H} \& \mathrm{E}$, 400X) (A). Pleomorphic sarcoma: Strong positivity for CD68 (IHC, 400X) (B)

\section{DISCUSSION}

Lymphedema is characterized by the presence of chronic lymphatic stasis, which impairs the local circulation of immune cells. ${ }^{1,2}$ When the local mechanisms of immune surveillance fail, the region becomes immunologically vulnerable and predisposed to cancer development. ${ }^{1}$ Several malignant lesions in areas of chronic lymphedema have been described, most commonly squamous cell carcinoma. BCC occurs less frequently.
Basal cell carcinoma is so designated by its cytological similarity to the basal cell layer of the epidermis. ${ }^{4,5}$ Usually, it expresses cytokeratins, bcl-2 and BerEP 4 but not epithelial membrane antigen (EMA), carcinoembryonic antigen (CEA) and vimentin ${ }^{4}$. The main risk factors for developing $\mathrm{BCC}$ include ultraviolet radiation exposure, genetic predisposition, light skin and old age. ${ }^{4,5}$ Besides these factors, immunosuppression is also reported as a risk factor for BCC. ${ }^{1,3}$

Anatomopathological examination of injuries 


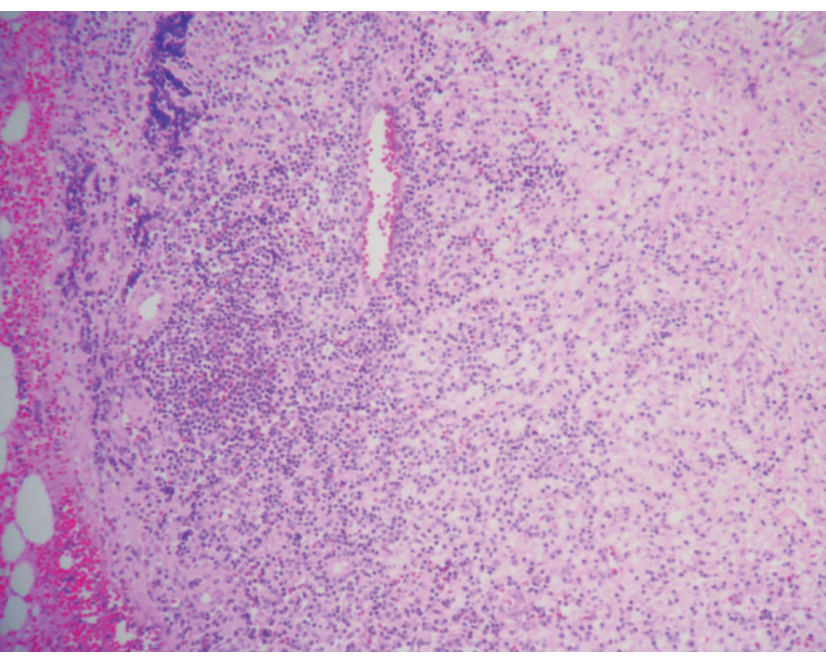

FIGURE 6: Lymph node parenchyma infiltrated by large, atypical and vacuolated cells, with histological profile similar to cutaneous sarcoma (H\&E, 200X)

arising from the surgical specimen showed varied patterns for the BCCs. Morphea-like basal cell carcinoma is an unusual clinical variant and is characterized by the presence of atypical basal cells in dense fibrous stroma. ${ }^{8}$ The relationship between metastasis and tumor histology is controversial in the literature. ${ }^{3,4,5}$

The BCC is the most common skin cancer, but its metastasization is rare and occurs when the lesions are long or have multiple recurrences. ${ }^{4,5}$ The most common sites are the lymph nodes (60\%), lung (40\%) and bone $(20 \%)^{5}$. Snow et al. found that lesions greater than $3 \mathrm{~cm}$ in diameter have a higher risk of metastasization. ${ }^{5}$ Perineural infiltration, overexpression of p53 protein and location in sun -protected areas are also associated with increased tumor aggressiveness. ${ }^{4,5}$ In this case, the size of the armpit BCC ( 4 $\mathrm{cm}$ ), associated with invasion of soft tissue, nerve bundles, blood vessel walls and the expression of $\mathrm{p} 53$ protein are factors that support local aggressive behavior and subsequent lymph node metastasis.

There are reports of sarcomas developing in areas of chronic lymphedema. ${ }^{2,9}$ Angiosarcomas are most commonly reported, originating from the breast or armpit after mastectomy for breast cancer (StewartTreves syndrome). ${ }^{2}$ Malignant fibrous histiocytoma (MFH) is a sarcoma that is rarely confined to the skin and subcutaneous tissue..$^{10}$ Leiomyosarcomas represent about $7 \%$ of soft tissue sarcomas and involvement of skin and subcutaneous tissue is uncommon. ${ }^{6}$ The intense and diffuse expression of CD68 suggests the presence of lysosomes in tumor cells or histiocytic differentiation. The focal positivity for HHF-35 and 1A4 indicates smooth muscle differentiation. Histological pattern and immunohistochemical profile are suggestive of a poorly differentiated pleomorphic sarcoma (pleomorphic MFH and/or pleomorphic leiomyosarcoma). The diagnosis of sarcoma is based on the infiltrative pattern of the neoplasm associated with areas of necrosis and lymph node metastasis. The main differential diagnosis is atypical fibroxanthoma, which may have histological pattern and immunohistochemical profile similar to primary pleomorphic sarcomas of the skin, but it shows no necrosis or metastasis. We also emphasize that we are unaware of any case of multiple BCCs concurrent with poorly differentiated pleomorphic sarcoma, with lymph node metastasis originating from the area of chronic lymphedema published in the literature.

\section{REFERENCES}

1. Ruocco V, Schwartz MD, Ruocco E. Lymphedema: an immunologically vulnerable site for development of neoplasms. J Am Acad Dermatol. 2002;47:124-7.

2. Schiffman S, Berger A. Stewart-Treves Syndrome. J Am Coll Surg. 2007;204:328

3. Ueno T, Futagami A, Mitsuishi T, Niimi Y, Shimoda T, Kawana S. Basal cell carcinoma arising on a chronic lymphedematous leg. J Dermatol. 2009;36:646-8.

4. Robinson JK, Dahiya M. Basal cell carcinoma with pulmonary and lymph node metastasis causing death. Arch Dermatol. 2003;139:643-8.

5. Snow SN, Sahl W, Lo JS, Mohs FE, Warner T, Dekkinga JA, et al. Metastatic basal cell carcinoma. Report of five cases. Cancer 1994;73:328-35.

6. Fleury LFF Jr, Sanches JA Jr. Sarcomas cutâneos primários. An Bras Dermatol. 2006;81:207-21.

7. Lotern M, Tamir G, Loven D, David M, Hauben D. Multiple basal cell carcinomas of the leg after recurrent erysipelas and chronic lymphedema. J Am Acad Dermatol. 1994; 31:812-3.

8. Jeevankumar B, Thappa DM. Unusual presentation of basal cell carcinoma on face. Indian J Dermatol. 2005;50:161-3
9. Fergusson CM, Copeland SA, Horton L. Unusual sarcoma arising in lymphedema. J Soc Med. 1985;78:497-8.

10. Siqueira RC, Jardim ML, Bandeira V, Ferreira RMCXC , Montenegro LT, Guimarães P, Batista V. Fibro-histiocitoma maligno de extremidade: relato de caso. An Bras Dermatol. 2004;79:569-73.
MAILING ADDRESS:
Giuliano da Paz Oliveira
Rua Desembargador José Lourenço, 248 - Noivos
64046-240 Teresina, PI
Tel: (86) 88154510
E-mail: giulianooliveira@botmail.com

How to cite this article: Oliveira GP, Girão RJS, Soares CT, Mello Junior EJF. Multiple metastatic basal cell carcinoma with concurrent metastatic pleomorphic sarcoma in chronic lymphedema area - Case report. An Bras Dermatol. 2012;87(6):899-902. 